\title{
A Estruturação do Sistema de Produção e Inovação Sucroalcooleiro como Base para o Proálcool ${ }^{*}$
}

\author{
Fabricio Brollo Dunham ${ }^{*}$ \\ Engenheiro do Banco Nacional de Desenvolvimento Econômico e Social (BNDES) \\ José Vitor Bomtempo \\ Gestão e Inovação Tecnológica, Escola de Química (UFRJ) \\ Grupo de Economia da Energia, Instituto de Economia (UFRJ) \\ Denise Lima Fleck \\ Instituto COPPEAD (UFRJ)
}

Recebido: 25/08/2008 Versão revisada (entregue): 04/05/2010 Aprovado: 17/08/2010

\section{RESUMO}

$\mathrm{O}$ artigo mostra como o processo de estruturação do Sistema de Produção e Inovaçãa Sucroalcooleiro - SPIS, no período anterior a 1975, pode ter sido importante para o sucesso do Programa Nacional do Álcool - Proálcool. Implementado em novembro de 1975, o Proálcool é considerado um programa de referência na substituição dos combustíveis líquidos fósseis por fontes renováveis de energia. A análise da estruturação do SPIS tomou como base o mapeamento das funçôes que influenciaram esse sistema, entre 1875 e 1975 . O artigo identifica seis motores que transformaram o SPIS, no período anterior a 1975, e que podem explicar as diferenças entre os modelos produtivos do Nordeste do Brasil e do Estado de São Paulo, a mudança no paradigma de desenvolvimento e seleção de variedades de cana, a formação do

* Os autores agradecem aos pareceristas anônimos pelas sugestões e comentários que muito contribuíram para a qualidade deste trabalho. Eventuais erros e/ou omissões são de inteira responsabilidade dos autores. José Vitor Bomtempo agradece o apoio do CNPq e da Capes.

** A opinião do autor não é necessariamente a opinião do BNDES. 
mercado de álcool combustível no Brasil, a expansão produtiva da agroindústria sucroalcooleira de São Paulo e sua interação com a indústria de equipamentos.

PalaVras-Chave | Álcool combustível; Etanol; Sistema de Inovação.

CÓdigo JEL | O32

\section{The Structuring of the Sugar Cane Innovation System: the roots of the Brazilian Ethanol Program (Proálcool)}

ABSTRACT This article shows the important role played by the structuration of the System of Production and Innovation in Sugar and Ethanol - SPIS - before 1975 in the success of the National Ethanol Program - Proálcool. This program was implemented in November 1975 and is considered a benchmark for the Brazilian capacity in substituting fossil liquid fuels for renewable sources of energy. The analysis of technological change in SPIS was based on maps of functions which influenced SPIS from 1875 to 1975. This article identifies six different motors that are accountable for the changes in SPIS before 1975. These motors can explain the differences between the productive models in the Northeast of Brazil and the State of São Paulo; the paradigmatic change in the way sugarcane varieties were developed and selected; the growth of ethanol market in Brazil; and the productive expansion of sugarcane industry in the State of São Paulo and its relationship with the equipment industry.

KEYWORDS | Combustible alcohol; Ethanol; System of Innovation.

JEL-CODE | O32 


\section{Introdução}

A acumulação tecnológica é um tema recorrente no debate sobre o processo de inovação. O conceito de path dependence explica como um conjunto de decisões é limitado por outras decisões tomadas no passado. O desenvolvimento tecnológico seria o produto de um conjunto de decisōes com certo grau de relacionamento entre si (NELSON; WINTER, 1982).

No Brasil, o Programa Nacional do Álcool - Proálcool é apontado como um marco no uso de biocombustíveis em larga escala. O período do Proálcool foi rico em investimentos em tecnologia, no aumento da produção e produtividade do álcool combustível. Dentro deste contexto, o artigo objetiva responder a uma pergunta central: qual a influência do período anterior a 1975 na formação de uma base para o Programa Nacional do Álcool - Proálcool?

Para alcançar este objetivo, optou-se pelo uso do conceito de sistema de inovação - SI, que oferece uma visão abrangente da inovação, possibilitando identificar os agentes envolvidos e o papel por eles desempenhado. A visão sistêmica e histórica do processo de inovação em álcool combustível permitiu captar aspectos relevantes para sua melhor compreensão. Ao se utilizar a abordagem de SI, é possível compreender como os agentes (empresas, instituições de pesquisa, fornecedores de tecnologias, etc.) se relacionam entre si. A análise destas relaçōes se mostra fundamental para entender como o Sistema de Produção e Inovação Sucroalcooleiro - SPIS estava estruturado antes do lançamento do Proálcool. A revisão dos conceitos de SI será apresentada na seção 2 .

A aplicação de uma abordagem sistêmica e dinâmica sobre a inovação requer dados e informações históricas bem fundamentadas. As informações históricas são o objeto sobre o qual o conceito de SI selecionado será aplicado. A pesquisa histórica do desenvolvimento do álcool combustível buscou identificar o esforço de P\&D realizado no Brasil, as escolhas tecnológicas e a participação dos agentes envolvidos com a agroindústria do açúcar e do álcool no período 1875 a $1975 .{ }^{1}$

1 É preciso frisar que a revisão aqui realizada não desconsidera o fato de que o açúcar de cana foi o primeiro produto de exportação introduzido no Brasil, ainda no início do século XVI (Celso Furtado, no clássico Formação econômica do Brasil, publicado originalmente em 1959, discute a importância estratégica da produção do açúcar de cana no esforço de colonização e defesa do território brasileiro. Em outro clássico, Casa grande \& senzala, de 1933, Gilberto Freire escreve sobre como a cultura dos senhores de engenho e de seus escravos influenciou na formação social do Brasil). A descrição que aqui se apresenta admite que a produção do açúcar de cana no Brasil é uma atividade econômica estruturada continuamente ao longo de cinco séculos. É fato que esta estruturação influenciou o ambiente em análise. Entretanto, pela revisão dos dados históricos e bibliográficos, foi considerado que uma revisão do período colonial não traria elementos relevantes para os objetivos do presente trabalho de tese. Por esta razão, o período colonial da produção de açúcar de cana foi desconsiderado, reforçando o ano de 1875 como ponto de partida. 
Apesar de terem produtos e mercados distintos, as agroindústrias do açúcar e do álcool são bastante relacionadas no Brasil. Tanto o álcool como o açúcar têm origem na mesma matéria-prima: a cana-de-açúcar. Açúcar e álcool são produtos alternativos e podem ser produzidos por praticamente todas as empresas do setor. As inovaçôes desenvolvidas para o álcool e o açúcar possuem efeitos potencialmente relacionados, especialmente quando realizados na fase agrícola da atividade. Por esta razão, ainda que tenham sido motivadas para a produção açucareira, diversas atividades influenciaram a estrutura disponível quando da implementação do Proálcool.

A metodologia do artigo, detalhada na seção 3 , se inspira nos conceitos de Hekkert et al. (2007), que propõem mapear os eventos que ocorrem dentro do SI em análise e que são relevantes para compreender o desenvolvimento de novos padrões tecnológicos. Os eventos que contribuem para o desenvolvimento, aplicação e difusão de novas tecnologias são denominados Funções dos Sistemas de Inovação - FSI. O objetivo final é associar os eventos às FSI, estruturando-as numa sequência lógica e temporal. Se isso for possível, tem-se um motor de transformação do SI.

Entretanto, a abordagem do artigo traz algumas diferenças em relação à proposta original de Hekkert et al. (2007). A primeira diferença é incluir a produção industrial como parte integrante do objeto de análise, entendendo que a tecnologia não é o único vetor capaz de transformar o SI. A segunda é diminuir a importância que os autores dão à FSI que determina o ponto de partida dos motores de transformação. No artigo, o objetivo é compreender como o motor se estruturou e qual seu impacto na estruturação do SI. A terceira diferença é considerar que a difusão e o uso das tecnologias - e não apenas o desenvolvimento de tecnologias - fazem parte do objetivo maior de todo SI.

A análise abrange o período de 1875 a 1975. O ano de 1875 foi escolhido como marco inicial em função do processo de modernização do setor açucareiro, implementado pelo governo imperial, enquanto o ano de 1975 compreende a publicação do decreto que formalizou a criação do Proálcool.

Por motivos de espaço, a síntese da revisão histórica encontra-se diretamente relacionada com a análise da estruturação do SPIS, o que tem lugar na seção 4. A discussão de cada motor de transformação será acompanhada da motivação da mudança, da inovação que induz às transformações e das FSI associadas ao processo de transformação, conforme o caso.

A seção 5 conclui o artigo, consolidando a análise da influência do período anterior a 1975 como base para a implementação do Proálcool. Especial atenção 
foi dada aos motores que falharam na transformação do SI, o que é importante para estudos comparativos com outros SI em biocombustíveis. A conclusão aponta ainda outras questões que surgem do processo de análise e que podem ser objeto de novos estudos.

\section{Discussão dos conceitos de sistema de inovação}

Na primeira parte desta seção, são revisados os conceitos dinâmicos de SI. Entretanto, para os objetivos do artigo, busca-se um conceito capaz de explicar o processo de transformação que acontece dentro dos SI. Como a mudança tecnológica ocorre? Que categorias de eventos influenciam a estruturação dos SI? A revisão bibliográfica indica que o trabalho de Hekkert et al. (2007) é um referencial para tratar estas questôes, sendo objeto de discussão na segunda parte desta seção.

\subsection{Conceitos dinâmicos de sistemas de inovação}

Ao menos três conceitos de SI trazem uma análise dinâmica de seus elementos, buscando identificar os desequilíbrios provocados pela inovação: sistema setorial de produção e inovação, na visão apresentada por Malerba e Orsenigo (1997) e Malerba (2004); sistema sociotécnico, de Geels (2004); e o motor de transformação dos SI, proposto por Hekkert et al. (2007).

Breschi e Malerba (1997) introduziram o conceito de sistema setorial de inovação na literatura, cuja principal ideia é de que os setores operam em diferentes regimes tecnológicos. A combinação das oportunidades, das condições de apropriação de resultados, da acumulação de conhecimentos tecnológicos e da base de conhecimentos é específica para cada setor.

Malerba (2004) avança na reflexão conceitual e passa a incluir as atividades de produção como parte do sistema de inovação. Segundo o autor, os sistemas setoriais de produção e inovação são compostos por um conjunto de agentes realizando interações de mercado e de não-mercado ${ }^{2}$ para criação, produção e venda de produtos setoriais. Os agentes dos sistemas setoriais de produção e inovação são organizações ou indivíduos com processos específicos de aprendizagem, competências, estrutura organizacional, crenças, objetivos e comportamentos. Os agentes interagem através

2 Interações de mercado são aquelas relacionadas com a compra e venda de bens e serviços. As interações de não-mercado compreendem atividades governamentais (regulação, fiscalização, etc.) ou a associação de empresas na defesa de interesses coletivos. 
do processo de comunicação, troca, cooperação, competição e comando, sendo que sua interação é moldada pelas instituiçôes. Um sistema setorial de produção e inovação realiza os processos de troca e de transformação por meio da co-evolução de seus vários elementos.

Ao apresentar os sistemas setoriais de produção e inovação, Malerba (2004) estuda o processo de transformação dinâmica dos sistemas, enfatizando o fato de que as fronteiras setoriais não são estáticas. Dois processos provocam a evolução das fronteiras dos sistemas: a criação de variedades e a seleção. O primeiro refere-se a produtos, tecnologias, empresas e instituições, assim como às novas crenças e estratégias que os agentes passam a adotar. A criação de novos agentes é particularmente importante na dinâmica da fronteira dos sistemas setoriais. A criação de variedades contribui para a mudança na população dos agentes da economia, assim como para a transformação das tecnologias utilizadas e os processos de produção.

Já a seleção de variedades desempenha o papel de reduzir a heterogeneidade, aplicando-se a empresas, produtos, tecnologias e demais elementos do sistema. A seleção se dá por meio de mecanismos de mercado e de não mercado, tais como as políticas de compras públicas. A seleção define o crescimento e o declínio dos grupos de atores, além de reduzir a faixa de atuação na qual as organizaçôes trabalham. A seleção pode ser mais ou menos intensa e frequente, variando em função do setor em análise.

Malerba e Orsenigo (1997) apresentam dois modelos de como os sistemas setoriais podem ser transformados: por meio de uma drástica ruptura (Schumpeter Mark I); ou pela contínua acumulação de conhecimentos (Schumpeter Mark II). No primeiro modelo, novas competências tecnológicas são requeridas. A introdução da inovação no mercado provoca turbulência na indústria e altera o posicionamento competitivo das empresas. No segundo, há um processo de evolução, em que a capacidade de acumular conhecimentos permite transformá-los em ganhos de produtividade. Neste caso, são comuns o domínio de empresas grandes e estabelecidas e a presença de barreiras à entrada.

A ideia de transformação, apresentada por Malerba e Orsenigo (1997) e Malerba (2004), é reinterpretada por Geels (2004), que avalia a mudança de um sistema para outro, sugerindo uma evolução do conceito de sistema setorial de inovação para um sistema sociotécnico. A base do conceito ainda é a geração, difusão e utilização de tecnologias, à qual o autor agrega três outras dimensōes: 1) incorpora os usuários no processo de análise; 2) sugere uma distinção analítica entre sistemas, atores e as instituições que guiam os atores; 3) amplia o enfoque nas instituições, fazendo com que sejam parte integral do processo de análise. 
Geels (2004) discute o surgimento de novos SI. A transição para um novo sistema só ocorre quando dois fatores estão combinados: a existência de uma janela de oportunidade, resultado das tensões no atual sistema; e a existência de uma inovação radical. As janelas de oportunidade surgem quando há tensões entre os elementos do sistema, provocadas por pressões externas ao sistema (ciclos políticos, movimentos culturais, ciclos de vida de produtos, existência de externalidades negativas, pressões sociais, demandas ambientais, etc.). Se uma tensão desestabilizar o sistema sociotécnico existente, uma inovação radical pode ser introduzida no mercado. Num primeiro momento, há uma competição do novo sistema com o sistema anterior e, se houver sucesso, sua substituição.

Apesar das contribuições de Malerba (2004), Malerba e Orsenigo (1997) e Geels (2004) para a análise da dinâmica dos SI, as abordagens estão limitadas a duas vertentes. A primeira enfatiza a avaliação das transformações dos SI em função da introdução de novas tecnologias ou de novos agentes - nos conceitos de Malerba (2004) e no padrão Shumpeter Mark I de Malerba e Orsenigo (1997). Entretanto, mantidos os mesmos agentes e as mesmas tecnologias, estes conceitos deixam de trabalhar outras questões, como, por exemplo, as transformações causadas por mudanças na forma como os agentes se relacionam. A segunda vertente se fixa no surgimento de novos SI - nos conceitos de Geels (2004) e no padrão Shumpeter Mark II de Malerba e Orsenigo (1997). Neste caso, a limitação é a necessidade do surgimento de um novo SI, o que não se aplica para uma análise histórica do processo de transformação do SPIS.

Para os objetivos deste artigo, busca-se uma ferramenta conceitual que possibilite compreender com maior clareza e precisão o processo de transformação dos SI. É preciso identificar as atividades que, ao serem realizadas pelos agentes, resultam na transformação dos SI. O estudo de Hekkert et al. (2007) é de grande interesse para subsidiar um trabalho desta natureza. Os autores indicam quais atividades (ou FSI, na terminologia dos autores) podem ser mapeadas e conjugadas na formação de motores de transformação, conceitos que serão detalhados a seguir.

\subsection{Motores de transformação dos sistemas de inovação}

Hekkert et al. (2007) trabalham a ideia de que a análise da mudança tecnológica deve-se apoiar no mapeamento das atividades que ocorrem no SI e que resultam na transformação da base tecnológica do SI. Uma vez que as atividades influenciam o direcionamento dos SI, os autores as denominam de Funções do Sistema de Inovação - FSI. 
Para Hekkert et al. (2007), o desafio de criar uma compreensão da dinâmica dos SI deve-se ao fato de que muitas atividades diferentes ocorrem ao mesmo tempo. Idealmente, seria necessário compreender todas as propriedades dinâmicas dos SI para entender o que realmente ocorre dentro deles. Há um conjunto considerável de variáveis que não poderiam ser mapeadas. É preciso mapear apenas as atividades relevantes, consideradas assim quando influenciam o objetivo do SI, que é desenvolver, difundir e viabilizar o uso de tecnologias e conhecimentos. As atividades que contribuem para isso são as FSI. As funções características dos sistemas de inovação são:

- FSI 1 - atividades empreendedoras;

- FSI 2 - desenvolvimento de conhecimento;

- FSI 3 - difusão de conhecimento através de redes;

- FSI 4 - direcionamento da pesquisa e do desenvolvimento tecnológico;

- FSI 5 - formação de mercado;

- FSI 6 - mobilização de recursos para a inovação;

- FSI 7 - criação de legitimidade e contenção da resistência à mudança.

\section{FSI 1 - atividades empreendedoras}

Não existe sistema de inovação sem empreendedores. O papel dos empreendedores é transformar o potencial de novos conhecimentos, redes de relacionamento e mercados em açóes concretas para gerar e tirar vantagem de novas oportunidades de negócio. Os empreendedores podem ser novos entrantes com visão de oportunidade em novos negócios, ou empresas existentes que diversificam sua estratégia de negócio para tirar vantagem de novos desenvolvimentos. A presença de atividades empreendedoras é o primeiro indicador do desempenho de um SI.

\section{FSI 2 - desenvolvimento de conhecimento}

A pesquisa, o desenvolvimento tecnológico e a criação de conhecimento são pré-requisitos para os sistemas de inovação. Três indicadores podem ser utilizados para mapear a função ao longo do tempo: projetos de $\mathrm{P} \& \mathrm{D}$, patentes e investimentos em P\&D.

\section{FSI 3 - difusão de conhecimento através de redes}

A função essencial das redes de relacionamento é estimular e possibilitar a troca informações. Isto é importante do ponto de vista estrito do P\&D, mas especialmente num contexto heterogêneo em que as atividades de $\mathrm{P} \& \mathrm{D}$ contemplam o governo, 
competidores e outros agentes de mercado. As redes de comunicação permitem a rápida difusão das inovações entre os usuários finais, bem como o feedback por parte dos usuários, permitindo ajustes e até mesmo o desenvolvimento de novos produtos.

\section{FSI 4 - direcionamento da pesquisa e do desenvolvimento tecnológico}

Como os recursos são quase sempre limitados, quando existem várias opções tecnológicas, é importante especificar um foco para realizar investimentos. Enquanto o desenvolvimento do conhecimento pode ser comparado à criação de variedade tecnológica, o direcionamento da pesquisa é o processo de seleção. Hekkert et al. (2007) sustentam que o direcionamento da pesquisa não é uma questão de influência governamental ou de mercado. Trata-se normalmente de um processo interativo e cumulativo de troca de ideias entre produtores de tecnologia, usuários de tecnologia e diversos outros atores, no qual a própria tecnologia não é uma constante, mas sim uma variável.

\section{FSI 5 - formação de mercado}

Normalmente, as novas tecnologias têm dificuldade de competir com tecnologias dominadas. Aquelas recém-desenvolvidas são, na maior parte dos casos, relativamente ineficientes e caras. Estas características tornam a difusão lenta e difícil. Nestes casos, são usados mecanismos para a criação de espaços protegidos para as novas tecnologias. Algumas possibilidades de proteção são a formação de nichos temporários de mercado, a implementação de regimes favoráveis de tributação e a definição de quotas mínimas de consumo.

\section{FSI 6 - mobilização de recursos para a inovação}

Recursos humanos e financeiros são insumos básicos para impulsionar as atividades dos sistemas de inovação. Para uma tecnologia específica, a alocação de recursos suficientes é necessária para viabilizar a produção de conhecimento. A mobilização de recursos pode ter origem nas empresas, que alocam orçamentos para a inovação, ou no governo, por meio de programas de financiamento específicos.

\section{FSI 7 - criação de legitimidade e contenção da resistência à mudança}

Normalmente, a adoção de uma nova tecnologia é acompanhada de um novo regime. ${ }^{3}$ Diferentes agentes com interesses contrários ao novo regime terão resis-

3 Neste contexto, o sentido da palavra regime é amplo. O regime pode estar relacionado às formas de uso de um produto, ao relacionamento entre os agentes do SI, ao surgimento de uma nova tecnologia, etc. 
tência à mudança. Grupos contra e a favor da tecnologia pressionarão por recursos para pesquisa, diferenciação tributária e demais formas de legitimar o uso da nova tecnologia.

Hekkert et al. (2007) argumentam que as FSI podem influenciar umas as outras. Em função das interações possíveis, podem ser formados motores de transformação do SI. O desempenho de uma determinada FSI pode iniciar o ciclo virtuoso de um processo de mudança, produzindo interações positivas com outras FSI e resultando na transformação do SI. O estudo empírico dos SI pode trazer ideias de como se formam os motores de transformação e de como influenciar a direção dos SI em termos nacionais e setoriais.

\section{Metodologia}

A metodologia escolhida para a elaboração do artigo tem por base o mapeamento dos eventos que ocorrem dentro do SPIS e que são relevantes para compreender o seu processo de transformação. A busca por informaçóes e dados não pode estar relacionada aos agentes que individualmente atuam no SPIS, devendo ser mapeados os eventos que influenciam todo o sistema. A pesquisa resulta num banco de dados históricos, construído com todos os eventos relevantes associados a uma tecnologia específica. Os eventos podem ser seminários sobre a tecnologia, início de projetos de $P \& D$, opinióes de especialistas sobre a tecnologia, anúncio de recursos para projetos, etc.

A obtenção dos dados foi realizada por meio da revisão dos relatórios do Ministério da Agricultura (1920 a 1938), da Revista Brasil Açucareiro (1950 a 1975) e de diversas outras publicações e teses sobre o setor.

Montado o banco de dados histórico, o segundo passo foi relacionar os eventos com as sete FSI conceitualmente descritas. Este procedimento permite ao pesquisador verificar a validade das funções para descrever as mudanças observadas no SI. Quando um número pouco significativo de eventos está relacionado a uma FSI, isto indica que a FSI não é relevante para a mudança tecnológica. Por outro lado, quando eventos significativos não conseguem se encaixar em uma das sete FSI, isto significa que a lista de funções não está completa. Novas FSI podem ser identificadas em função dos trabalhos empíricos.

A partir do conjunto de FSI mapeadas, é preciso verificar como cada FSI influenciou no desenvolvimento das tecnologias do SI e, ao mesmo tempo, como cada FSI influenciou as outras FSI. Tem-se um motor de transformação do SI quando as 
FSI podem ser encadeadas numa sequência lógica e temporal. O motor de transformação deve ser capaz de explicar como o desenvolvimento do SI ocorreu ao longo do tempo e qual o papel das FSI nisso. Ainda que existam sete FSI caracterizadas, Hekkert et al. (2007) argumentam que um pequeno número de FSI pode justificar o início do processo de mudança a ponto de formar um motor de transformação. Os autores fixam este ponto como um fator relevante do processo de análise.

Avaliando a metodologia de Hekkert et al. (2007), algumas observaçôes podem ser apontadas neste artigo. A primeira diz respeito à ênfase dos autores na tecnologia. A mudança tecnológica seria o principal vetor de transformação do SI. Entretanto, acredita-se que outros fatores, além da tecnologia, podem trazer significativas transformações aos SI e, por isso, devem ser incorporados na análise. Para Malerba (2004), a produção industrial deve ser entendida como parte integrante dos SI. Da mesma forma, Geels (2004) enfatiza a difusão e o uso das tecnologias (e não apenas o desenvolvimento de tecnologias) como fatores relevantes dentro dos SI. Assim, para os fins deste artigo, a análise incluirá a produção industrial e a difusão e o uso de tecnologias como fatores substantivos para a transformação do SPIS.

A segunda observação é que o número e a abrangência das FSI mapeadas dependem diretamente do período analisado. Espaços curtos de tempo podem empobrecer o processo de identificação das FSI que explicam determinada transformação do sistema. Para os objetivos do artigo, 1875 é um marco no processo de modernização da agroindústria sucroalcooleira com a publicação do Decreto 2.687/1875 e será o ano inicial do período de análise. A referência final é a publicação do Programa Nacional do Álcool - Proálcool, lançado em novembro de 1975.

A terceira observação refere-se ao enfoque dado pelos autores à FSI que determina o ponto de partida dos motores de transformação. Os autores sugerem cuidado com a análise e identificação da FSI que inicia o motor de transformação. Para o artigo, o foco será o impacto das FSI na estruturação e no crescimento do SI. Os motores de transformação serão montados tendo em vista os resultados alcançados no SI. O ponto relevante corresponde ao encadeamento lógico e temporal das FSI, independente de quais FSI proporcionam o início do motor de transformação.

A quarta observação é que, na avaliação dos autores, os motores de transformação podem transformar o SI de maneira positiva ou negativa. Ou ainda: uma sequência de FSI pode ser encadeada, mas não resultar em transformação alguma; o motor de transformação pode falhar em seu processo de desenvolvimento. A análise de situações desta natureza é relevante para compreender as falhas nos motores e será incorporada no artigo. 
Por fim, cada motor de transformação identificado, tenha ele obtido sucesso ou não, deverá ser descrito com os seguintes elementos:

- Motivação da mudança - Que objetivos se desejava alcançar? Que fatores (econômicos, sociais, legais, etc.) impulsionaram o processo de mudança?

- Inovação - A transformação dos SPIS ocorre em função de inovações, no sentido mais amplo do conceito. Qual a inovação-chave do motor em análise? A inovação compreende atividades de desenvolvimento, difusão ou uso de tecnologias?

- Funções do sistema de inovação - Quais eventos estão associados a quais FSI? Como as FSI se encadeiam numa sequência lógica e temporal? As FSI reforçam umas as outras, ou não?

- Resultados obtidos - Houve a transformação do SPIS? Qual foi esta transformação? Ela foi positiva ou negativa? Que outros impactos a transformação do SPIS ocasionou?

\section{A estruturação do sistema de inovação em álcool combustível}

A produção de açúcar é uma atividade que remonta o início do século XVI. Entretanto, a partir de 1875, o SPIS sofreu transformaçóes que o impulsionaram para uma nova configuração. Foram identificados seis motores de transformação que influenciaram a estruturação do SPIS no período anterior ao Proálcool:

- processo de modernização de 1875 e instalação dos engenhos centrais;

- superação da crise do mosaico;

- formação do mercado de álcool combustível;

- desenvolvimento de variedades de cana após a crise do mosaico;

- expansão produtiva da agroindústria sucroalcooleira em São Paulo;

- relacionamento da agroindústria sucroalcooleira com a indústria de equipamentos.

Os motores identificados resultaram num SPIS mais complexo, em que o relacionamento entre os agentes foi radicalmente modificado. Para facilitar os leitores, a Figura 1 localiza cada um dos seis motores no tempo. 
FIGURA 1

Localização temporal dos motores de transformação identificados para o SPIS
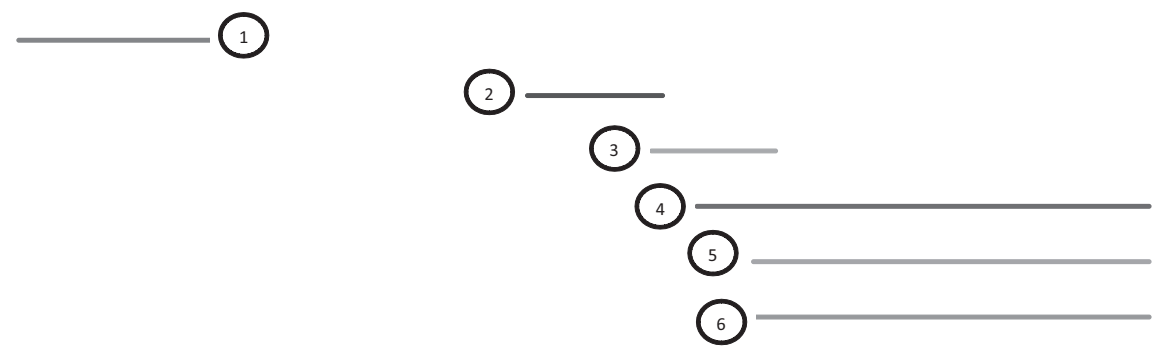

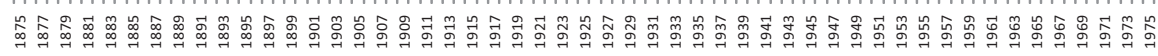

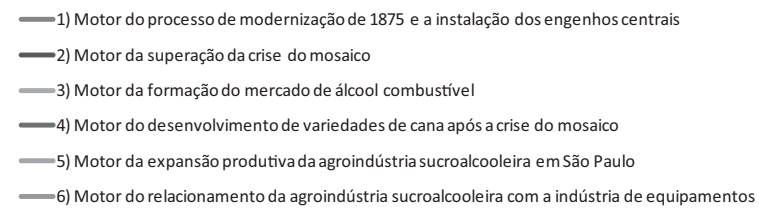

Fonte: Elaboração própria.

\subsection{0 processo de modernização de 1875 e a instalação dos engenhos centrais}

O processo de modernização da agroindústria sucroalcooleira iniciou-se na década de 1870 . Foi a partir de 1873 que um pequeno grupo de senhores de engenho de Pernambuco começou a modernizar as instalações produtivas com a aquisição de máquinas e equipamentos (EISENBERG, 1977). O governo imperial respondeu ao início do processo de modernização com a publicação do Decreto 2.687/1875, que garantiu financiamento com juros de $7 \%$ ao ano e prazos de 5 a 30 anos para os empresários que desejassem estabelecer engenhos centrais de açúcar (BRASIL, 1875). Os engenhos centrais eram unidades exclusivamente dedicadas às atividades industriais do beneficiamento do açúcar. A cana-de-açúcar seria entregue aos engenhos centrais por fornecedores agrícolas, cuja relação seria estabelecida em contrato. No antigo engenho colonial, método semiartesanal de produção, as moendas eram alimentadas com canas cultivadas nas áreas de seus respectivos proprietários.

O Decreto 2.687/1875 constitui um marco no processo de modernização da agroindústria sucroalcooleira, representando a decisão política do Império em 
melhorar a competitividade do açúcar brasileiro no mercado externo. A política de incentivos financeiros perduraria até meados da década de 1890, sofrendo alterações em favor dos tomadores de crédito (BRASIL, 1881; 1889). O direcionamento de recursos foi firme e duradouro, caracterizando a FSI de mobilização de recursos.

Ainda que o governo imperial tenha oferecido incentivos financeiros para a instalação dos engenhos centrais ${ }^{4}$ - apoio que foi mantido no período republicano -, o processo de modernização da agroindústria sucroalcooleira no Brasil teve alcance limitado. Entre 1875 e 1892, foram autorizadas 101 concessões de financiamentos para a construção de engenhos centrais. Destas, 54 foram revogadas por decurso de prazo ou pela simples desistência de seus beneficiários. Apenas 37 empreendimentos tiveram seus planos de obras, projetos e contratos de fornecimentos de cana aprovados.

Em 1891, o Ministério da Agricultura avaliou que o resultado da modernização da agroindústria sucroalcooleira no Brasil era insuficiente. Apesar da alta demanda pelos recursos, a maior parte dos interessados era formada por pessoas estranhas ao setor que, segundo o Ministério, tinham por objetivo negociar as concessōes obtidas. O Ministério da Agricultura registrou a existência de 13 engenhos centrais em operação, número diferente dos oito verificados com a análise dos decretos do período (MACOP, 1891).

Mesmo considerando a existência de 13 engenhos centrais, este número é inexpressivo quando comparado ao total de engenhos existentes no país. Em 1877, havia cerca de 2.600 engenhos nos Estados de Pernambuco, Alagoas, Sergipe e Bahia. Considerando que estão ausentes desse levantamento os Estados de Minas Gerais, Rio de Janeiro e São Paulo, é bastante razoável confirmar que a modernização da agroindústria sucroalcooleira não ocorreu na extensão planejada pelo governo (DNP, 1938).

A mobilização de recursos tinha por objetivo gerar estímulos aos empreendedores, de forma que estes se interessassem pela instalação de engenhos centrais. A política de modernização seria concretizada com a instalação e operação de novas unidades industriais, com processos de produção mais modernos, o que não ocorreu. A inovação pretendida era exógena à indústria e seria fornecida pelos fabricantes de equipamentos, principalmente franceses e ingleses. Os projetos autorizados a funcionar representaram cerca de $8 \%$ do total de concessões

4 Os engenhos centrais eram instalações que, para todos os efeitos práticos, podiam ser comparados às atuais usinas de cana. Os tradicionais engenhos eram unidades de pequeno porte que utilizavam tração animal, humana ou quedas d'água para movimentar as moendas. Os engenhos centrais eram unidades industriais modernas, que processavam grandes volumes de cana e utilizavam vapor d'água para o trabalho das moendas. 
efetuadas. A FSI de atividades empreendedoras falha e o motor de transformação do SPIS não se efetiva.

A baixa mobilização para atividades empreendedoras é a principal razão do não funcionamento do motor de transformação. Entretanto, o desenvolvimento do motor também esbarrou na resistência ao novo regime de trabalho. A FSI de criação de legitimidade e contenção da resistência à mudança era necessária ao motor de transformação, mas não se desenvolveu.

Queda (1972) observa que a característica fundamental na constituição dos engenhos centrais era a separação da fase agrícola (a produção de cana-de-açúcar) da fase industrial (a produção do açúcar). A construção dos engenhos centrais exigia capitais em volume que a maioria dos senhores de engenho não podia mobilizar, mesmo com os incentivos do governo.

Com o aumento da escala das unidades agroindustriais, a instalação dos engenhos centrais implicou uma escolha forçada. Os empresários do setor que não se tornassem proprietários de engenhos centrais teriam a opção de permanecer na fase agrícola de produção, tornando-se fornecedores de cana, ou sair da atividade. Enraizados na tradicional cultura do poder fundiário e com pouca disponibilidade de capital, grande parte dos senhores de engenho permaneceu na fase agrícola da produção. Queda (1972) analisou essa escolha, confirmando que a opção por se manter na atividade agrícola partiu dos próprios senhores de engenho.

A separação das atividades agrícola e industrial iniciou uma série de conflitos entre fornecedores de cana e industriais, que envolviam os valores pagos pela cana, o volume de produção, a garantia de compra da cana-de-açúcar, entre outros aspectos. As disputas de poder eram especialmente presentes no norte fluminense e na Região Nordeste, onde a cana-de-açúcar era uma cultura secular. $\mathrm{O}$ poder político dos antigos senhores de engenhos passou a ser exercido pelos novos fornecedores de cana. Ainda que não detivessem o poder econômico, agora com os engenhos centrais, os fornecedores de cana formavam uma classe influente no plano político.

O modelo de modernização do final do século XIX é um exemplo de como a adoção de uma inovação (o engenho central) é acompanhada de um novo regime. No caso, não se trata de um regime tecnológico, mas sim de um novo regime socioorganizacional, envolvendo a divisão de trabalho e poder.

Passados 14 anos desde sua criação, a política de modernização incorporou um segundo fator: o direcionamento tecnológico. O Decreto 10.393/1889 incentivou 
a adoção do método de difusão na instalação dos engenhos centrais, instituindo a preferência na concessão dos recursos. ${ }^{5}$

A implementação do método de difusão em Pernambuco exemplifica o resultado obtido com o direcionamento tecnológico. Naquele Estado somente dois engenhos centrais instalaram máquinas de difusão: as Usinas Ipojuca e Cacaú. A experiência obtida na primeira foi insatisfatória e o proprietário logo retornou ao método convencional de moendas. Já a Usina Cacaú teve mais êxito, resolvendo o problema de combustível por meio da instalação de uma fornalha para secar o bagaço antes da queima. Apesar dos resultados favoráveis, quando o proprietário decidiu ampliar a produção adquiriu uma moenda tradicional para trabalhar em paralelo ao método de difusão (EISENBERG, 1977).

Ainda que o relato anterior não seja preciso quanto ao ano em que ocorreu e se os proprietários tiveram ou não financiamento público, o fato principal é que o método da difusão não foi adotado no Brasil. A resistência ao método de difusão para a produção de açúcar de cana pode ser observada no Decreto 819/1890. No texto, o governo faculta que as empresas adotem o sistema de difusão ou de expressão (moendas), conforme seus próprios interesses (BRASIL, 1890). Apesar de prever a faculdade de retomar o direcionamento tecnológico, opção nunca exercida, o governo reconhecia a resistência ao novo regime tecnológico e cedia à pressão dos empresários do setor. Por mais este motivo, o motor de transformação não se desenvolveu. A Figura 2 resume as relaçōes entre as FSI para o processo de modernização de 1875 .

A modernização da agroindústria do açúcar não ocorreu na extensão desejada. Não houve a transformação do SPIS no sentido pretendido pela política governamental. Entretanto, a criação de uma nova categoria de atores - os fornecedores de cana - foi um subproduto concreto e duradouro. Trata-se de um resultado colateral que produziu efeitos na agroindústria sucroalcooleira por quase um século.

5 Parazzi e Ferrari (1981) explicam que o método de difusão consiste em cortar a cana longitudinalmente, mergulhando-a repedidas vezes em água, que lava ao xarope. O método da difusão foi inventado pelos produtores de açúcar de beterraba e substitui os tradicionais rolos de esmagamento por lâminas de corte. O processo era defendido com o argumento de que extraía maior percentual do puro xarope de cana. Entretanto, tinha a desvantagem de requerer maior volume de combustível para a evaporação da água e paradas sistemáticas para o afiamento das lâminas. 
FIGURA 2

Representação esquemática do motor de transformação do processo de modernização da agroindústria açucareira

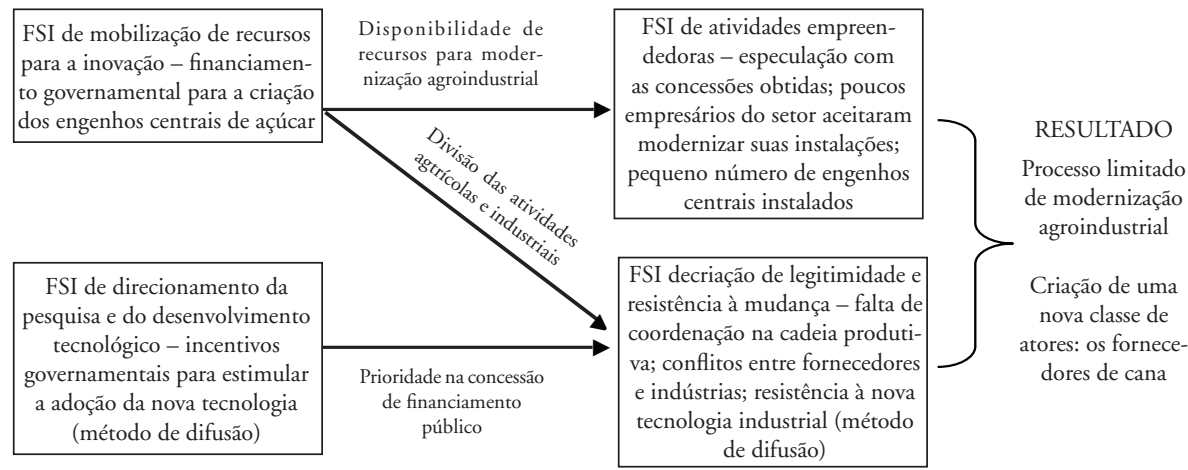

Fonte: Elaboração própria.

\subsection{Superação da crise do mosaico}

A crise do mosaico foi determinante para a futura estruturação do SPIS. Ocorrida no início da década de 1920, ou seja, antes da efetiva formação do mercado de álcool combustível, as açôes implementadas para superar a crise do mosaico alteraram a conduta dos agentes produtivos. O mosaico da cana trouxe impacto negativo na produção agrícola. O Estado de São Paulo foi o primeiro a ser atacado pelo mosaico no Brasil, tendo sua produção reduzida a menos de um quarto entre 1922 e 1925. A manutenção da atividade canavieira foi a principal motivação dos agentes do SPIS para a busca de soluções.

Oliver (2001) e Oliver e Szmrecsányi (2003) trazem uma avaliação bastante minuciosa dos eventos que resultaram no controle do mosaico. A superação da crise do mosaico teve início com o direcionamento da pesquisa agrícola. Direcionamento este entendido como a opção entre desenvolver novas variedades ou selecionar variedades de cana entre as existentes no Brasil e no exterior. A urgência do problema do mosaico e as condições técnicas disponíveis impulsionaram a Estação Experimental de Cana de Piracicaba - EECP a escolher a seleção de variedades com opção no direcionamento da pesquisa, otimizando a aplicação dos recursos disponíveis. Apesar de ter alcance de curto prazo, a seleção de variedades foi a estratégia vencedora no direcionamento da pesquisa agrícola. A afirmativa é respaldada quando se compara o direcionamento da EECP com o da Estação Experimental de Cana de Campos - 
EECC. Em Campos dos Goytacazes - município do norte fluminense -, a opção foi pelo desenvolvimento de novas variedades de cana, o que deixou de atender ao fator de urgência imposto pelo mosaico. A EECC não conseguiu produzir nenhum resultado satisfatório durante a crise do mosaico, acabando por seguir a trajetória de seleção de variedades, tal como a EECP.

Feita a opção pelo direcionamento da pesquisa, a EECP estabeleceu um programa de seleção de variedades, identificando aquelas mais resistentes ao mosaico, por meio da avaliação de um grande número de cultivares testadas em diversas condiçôes de solo e clima. $\mathrm{O}$ esforço de seleção de variedades da EECP foi complementado por uma rede de oito usinas com campos de experimentação próprios, que representavam $55 \%$ da produção paulista de açúcar, demonstrando a abrangência das ações da EECP. Após a seleção prévia da EECP, os campos de experimentação das usinas serviam para refinar o trabalho de pesquisa. A participação de técnicos e agrônomos das usinas permitiu a rápida difusão de conhecimentos para o SI, que adotou as novas variedades e técnicas de manejo. $\mathrm{O}$ estreito relacionamento entre uma instituição pública de pesquisa e as empresas do setor era um elemento novo na agroindústria sucroalcooleira.

Os agentes paulistas do SI desenvolveram duas competências fundamentais para superar o problema do mosaico: desenvolvimento de conhecimentos para enfrentar o desafio que se apresentava, buscando resultados de maneira eficiente; e difusão dos resultados no setor produtivo, o que só foi possível em função da cooperação com as usinas. $\mathrm{O}$ evento do mosaico encadeou a FSI de geração de conhecimentos e a FSI de difusão de conhecimentos.

Com estas competências, entre 1926 e 1932, as variedades preta e rosa, suscetíveis ao mosaico, tinham sido completamente substituídas pelas javanesas POJ-36, POJ-213 e POJ-228. A substituição das variedades ocorreu rapidamente: em 1929 chegava a 85\%, alcançando 99\% em 1932 (QUEDA, 1972; OLIVER, 2001). As Figuras 3 e 4 trazem a representação esquemática do segundo motor de transformação identificado para o SPIS, respectivamente, no Estado de São Paulo e no norte fluminense.

O motor que possibilitou superar a crise do mosaico contribuiu, de fato, para a manutenção da produção açucareira. Entretanto, sua ação foi centrada na atividade agrícola, onde a cana-de-açúcar é matéria-prima comum ao açúcar e ao álcool. Em última análise, a crise do açúcar provocada pelo mosaico da cana poderia ter inviabilizado a futura produção de álcool combustível. 
FIGURA 3

\section{Representação esquemática do motor de transformação da crise do mosaico no} Estado de São Paulo

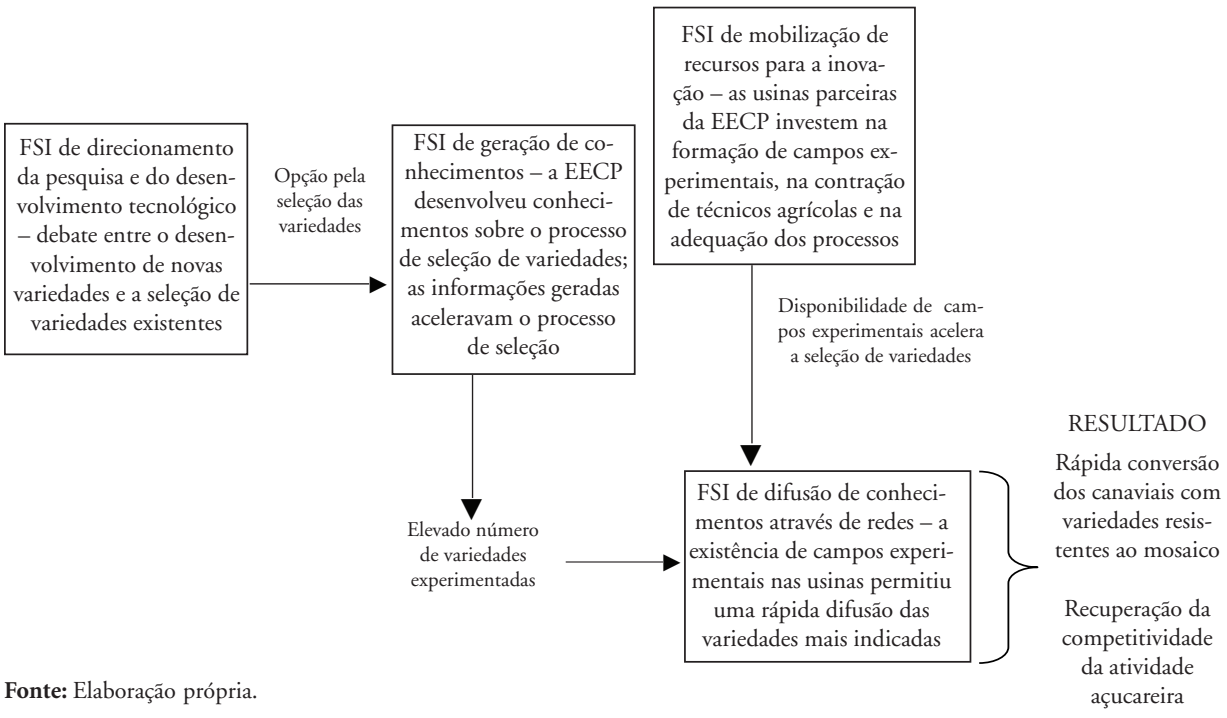

FIGURA 4

Representação esquemática do motor de transformação da crise do mosaico no norte fluminense

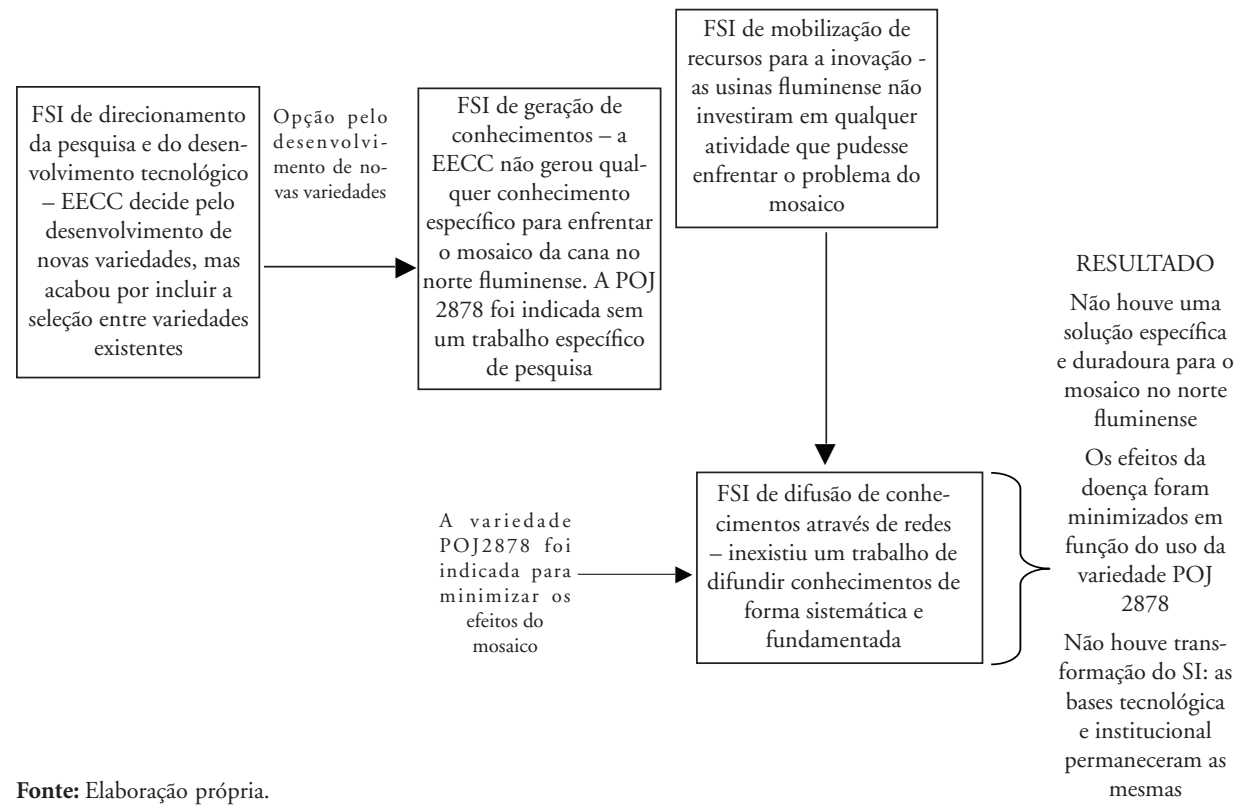


O motor de transformação não proporcionou apenas a superação da crise do mosaico. A mudança mais profunda foi na forma de executar a pesquisa agrícola em cana-de-açúcar. A parceria das instituições de pesquisa com as usinas seria fortalecida. O modelo de rede da EECP seria o mesmo a ser utilizado pelo Instituto Agronômico de Campinas - IAC, quando este sucedeu à EECP em 1935, e mais tarde pelo Centro de Tecnologia da Coopersucar - CTC, instituição privada criada em 1970.

\subsection{Formação do mercado de álcool combustível}

O terceiro motor de transformação identificado como base para o SPIS tem a formação do mercado de álcool como resultado mais importante. O motor é motivado pelas crises de superprodução de açúcar do final do século XIX e início do $\mathrm{XX}$, que deprimiram os preços e as margens de lucro. A fabricação de álcool para fins carburantes tinha o objetivo de absorver o excedente da produção de açúcar.

A iniciativa de utilizar o álcool como combustível automotivo teve início com a articulação dos produtores em prol de novos usos para o álcool. Em outubro de 1903, a Sociedade Nacional de Agricultura - SNA promoveu a Exposição Internacional de Aparelhos de Álcool, evento que foi acompanhado do Congresso Internacional do Álcool. O objetivo de ambos os eventos foi apresentar propostas para ampliar o uso do álcool como fonte de calor, iluminação pública e força motriz em geral. Uma das propostas apresentadas foi a do uso do álcool em veículos automotores. Entretanto, tratava-se de um mercado de pequeno potencial, uma vez que a frota brasileira de veículos, no início do século XX, era igualmente pequena (SNA, 1904).

A substituição da gasolina pelo álcool ganharia força no início da década de 1920. O $3^{\circ}$ Congresso Nacional de Agricultura, realizado em 1922, fez sugestôes específicas com relação ao uso do álcool combustível, tais como: formação de uma "Liga Nacional de Defesa e Propaganda do Álcool-Motor"; reconhecimento do álcool-motor como de "utilidade pública" e de "interesse nacional"; criação, no Ministério da Agricultura, de uma seção dedicada a resolver as questóes técnicas da industrialização do álcool-motor. Na mesma linha seguiram o Congresso da Agricultura do Nordeste Brasileiro, em janeiro de 1923, e as demonstraçōes promovidas pela SNA a partir de 1921, que fez propaganda das vantagens do álcool utilizando um veículo próprio movido a álcool. A SNA solicitou a redução de impostos para

\footnotetext{
6 Álcool-motor é a denominação genérica dada às misturas de álcool hidratado com outros produtos fósseis, tais como éter, querosene e até mesmo a gasolina.
} 
carros a álcool e protestou contra a flutuação de preços do álcool, o que dificultava sua difusão como combustível (SANTOS, 1982).

É preciso observar que a pressão surgiu dos industriais do açúcar, que perceberam no álcool uma alternativa para reduzir os efeitos das repetidas crises no mercado açucareiro. Até o final da década de 1920, a ação dos agentes produtivos limitou-se à FSI de legitimidade para as novas aplicações do álcool. A pressão era dirigida ao governo, no intuito de que este solucionasse o problema da crise internacional do açúcar.

A inércia da iniciativa privada seria rompida em 23 de junho de 1927, no Recife, com o lançamento do primeiro combustível nacional de álcool-motor. $\mathrm{O}$ USGA - iniciais de Usina Serra Grande Alagoas - era uma mistura de 55\% de álcool hidratado e $45 \%$ de éter. Tratava-se da primeira iniciativa de uma usina de açúcar em atuar no mercado de combustíveis líquidos. Até o início da década de 1930, outras formulações de álcool-motor foram lançadas comercialmente pelas agroindústrias do setor, destacando-se a Azulina, a Motorina e o Cruzeiro do Sul (MELO, 1942).

O lançamento de misturas de álcool-motor pela agroindústria sucroalcooleira representou a efetiva realização de atividades empreendedoras, caracterizando esta FSI. Ainda que as repetidas crises do mercado açucareiro impelissem as empresas agroindustriais na busca por alternativas, a entrada no mercado de combustíveis era uma ruptura significativa com o padrão dominante de conduta.

Com a crise de 1929, diversas forças se fundiram para a efetiva formação do mercado de álcool combustível. Em consequência da crise econômica mundial, o mercado interno ficou contraído e os preços e as exportações declinaram com forte prejuízo aos empresários. Santos (1982) argumenta que estes fatores, somados ao dirigismo estatal do governo Getúlio Vargas, impulsionaram o governo a adotar medidas para a defesa da produção açucareira.

Entre as medidas propostas, surgiu o Decreto 19.717/31, que estabeleceu a mistura compulsória de 5\% de álcool anidro na gasolina importada (BRASIL, 1931a). $\mathrm{O}$ texto trouxe uma série de incentivos para estimular a produção e o consumo da mistura gasolina-álcool anidro. Foram dados incentivos para a importação de equipamentos, redução de impostos, de tarifas, de frete e outras. O governo também oficializou o uso do álcool-motor, instituindo a Comissão de Estudos sobre Álcool-Motor, em agosto de 1931 (BRASIL, 1931b).

Em resposta à política do álcool combustível, a produção brasileira cresceu significativamente entre 1932 e 1940 . A aquisição e uso de equipamentos de destilação do álcool anidro foi a inovação sobre a qual se desenvolveu o motor. Assim 
como no final do século XIX, a fonte de inovação era exógena ao SPIS. O governo concedeu uma série de incentivos para importação de equipamentos e produtos para a desidratação do álcool, o que surtiu resultado. A Tabela 1 apresenta a evolução do número de destilarias e da produção de álcool anidro.

TABELA 1

Produção e número de destilarias de álcool anidro Brasil - 1932-1940

\begin{tabular}{c|c|c|c}
\hline Ano & $\begin{array}{c}\text { Produção de álcool anidro } \\
\text { (em litros) }\end{array}$ & $\begin{array}{c}\text { Número de destilarias } \\
\text { instaladas }\end{array}$ & $\begin{array}{c}\text { Capacidade anual } \\
\text { de produção } \\
\text { (em mil litros) }\end{array}$ \\
\hline 1932 & - & - & - \\
1933 & 100.000 & 1 & 1.800 \\
1934 & 911.861 & 5 & 7.200 \\
1935 & 5.411 .429 & 14 & 20.775 \\
1936 & 18.462 .432 & 26 & 41.250 \\
1937 & 16.397 .781 & 27 & 56.550 \\
1938 & 31.919 .934 & 30 & 64.050 \\
1939 & 38.171 .502 & 31 & 65.550 \\
1940 & 53.473 .533 & 38 & 85.800 \\
\hline
\end{tabular}

Fonte: Mello (1942).

O terceiro motor de transformação do SI resultou na construção e consolidação do mercado de produção e uso de álcool combustível. O Decreto 19.717/31 pode ser considerado o marco inicial da atividade alcooleira em larga escala. A partir de 1931, o Brasil passou a utilizar o álcool anidro em misturas com a gasolina. O uso do álcool hidratado puro só teve início em 1979, o que foge ao escopo de análise deste trabalho. A Figura 5 apresenta o motor de transformação relacionado à formação do mercado de álcool combustível. 
FIGURA 5

Representação esquemática do motor de transformação da formação do mercado de álcool

FSI de criação de legiti-
midade e contenção da
resistência à mudança
- pressão dos industriais
do açúcar para escoar
o excesso de produção
de açúcar; pressão para
o desenvolvimento de
novos usos para o álcool melhorar o mercado de açúcar
FSI de geração de conhecimentos - EECM busca compreender os efeitos do uso do álcool combustível nos motores; desenvolvimento de soluçōes para adaptar o combustível aos motores triais do açúcar tomam a iniciativa de lançar os primeiros combustíveis de álcool-motor; iniciativa de construir novos usos para o álcool

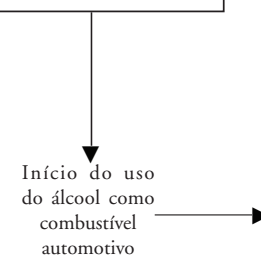

RESULTADO

Rápido aumento da produção de álcool anidro;

Consolidaçãoo do álcool anidro como combustível aditivo à gasolina

Fonte: Elaboração própria.

\subsection{0 desenvolvimento de variedades de cana após a crise do mosaico}

O início da década de 1930 trouxe um dos mais complexos motores de transformação do SPIS. Trata-se do motor de desenvolvimento de variedades de cana-de-açúcar. A transformação do SPIS ocorreu em torno da mesma tecnologia básica: desenvolvimento/seleção de variedades de cana. Entretanto, a motivação não era mais vencer o mosaico. $\mathrm{O}$ objetivo era aumentar a produtividade agroindustrial por meio da maximização do rendimento agrícola, o que seria obtido com o de- 
senvolvimento de variedades de maior conteúdo de sacarose e de maior resistência a pragas e doenças.

A FSI de direcionamento da pesquisa pode ser identificada nas duas instituiçóes mais relevantes no melhoramento genético da cana-de-açúcar. Em 1935, o IAC sucedeu a EECP e direcionou seus esforços na construção de um amplo sistema de seleção de variedades, contando com a participação das usinas (JÚNIOR, 1936). O IAC repetia o modelo que, na década de 1920, tinha possibilitado debelar o mosaico da cana. A EECC, por outro lado, investiu fortemente na criação de novas variedades a partir da década de 1940, adotando protocolos de cruzamento e seleção rigorosos (EECC, 1963).

Em ambos os casos, a FSI de desenvolvimento de conhecimentos é identificada. Em São Paulo, o IAC e as usinas parceiras passaram a conhecer o comportamento das diferentes variedades em função do tipo de solo, clima e técnicas de manejo. Estes atores puderam aprofundar os conhecimentos de que dispunham para decidir sobre as melhores condições de plantio, indicaçōes de variedades, adubação, irrigação, etc. A indicação de uma variedade apresentava especificidades; o resultado final tinha pequena capacidade de ser replicado. Entretanto, os conhecimentos gerados sobre o comportamento de cada variedade e a metodologia utilizada para os experimentos eram plenamente replicáveis, facilitando a incorporação de novas usinas ao sistema de cooperação. Na EECC houve geração de conhecimentos sobre o comportamento das plantas e seu potencial de transmitir características desejáveis aos descendentes. A EECC passou a dominar conhecimentos específicos sobre a biologia e genética da cana-de-açúcar. Apesar do baixo número de variedades lançadas, os cultivares da EECC foram utilizados em todo o Brasil com grande êxito, especialmente na Região Nordeste e até mesmo em São Paulo.

Até este ponto, o motor de transformação traz atividades complementares e positivas para a evolução do SPIS. Entretanto, a FSI de difundir conhecimentos por meio de redes evoluiu com eficiência apenas no caso paulista. O IAC desempenhou o papel de coordenar uma ampla rede de usinas, proporcionando maior difusão de conhecimentos dentro do setor produtivo, e acabou por difundir os conhecimentos gerados pela EECC na forma de seleção e recomendação de uso das novas variedades.

Para interagir de maneira eficiente com o IAC, as usinas parceiras precisaram se capacitar, contratando agrônomos e técnicos agrícolas e formando campos de experimentos e outros investimentos. As empresas paulistas participantes da difusão de conhecimentos coordenada pelo IAC mobilizaram recursos para a inovação, aumentando assim seu potencial de crescimento e competitividade. Em 1946, as 
usinas parceiras do IAC respondiam por $73 \%$ da produção paulista (OLIVER, 2001), o que fornece a dimensão do impacto da FSI de difusão de conhecimentos.

No Nordeste do Brasil e no norte fluminense não houve um agente que cumprisse o papel desempenhado pelo IAC, ou seja, organizar as atividades de assistência técnica agrícola em larga escala e com alta qualidade. A expectativa dos usineiros nordestinos e fluminenses era de que esse trabalho fosse realizado por uma instituição pública. Entretanto, parece equivocado acreditar que a falta de um agente público tenha sido a razão fundamental para a não difusão de conhecimentos nas duas regiōes produtivas. A análise da Revista Brasil Açucareiro (diversos números, período de 1940 a 1950) indica que as empresas nordestinas e fluminenses aparentemente não mobilizaram recursos e não se organizaram para suprir esta lacuna.

A criação do Plano Nacional de Melhoramento da Cana-de-açúcar - Planalsucar, em 1969, não trouxe alterações na condução do motor de transformação. O Planalsucar foi conduzido pelo Instituto do Açúcar e do Álcool - IAA e sucedeu as estações experimentais vinculadas à União, mantendo o foco na criação de variedades de cana-de-açúcar. Houve um significativo aumento na capacidade de gerar variedades e de aumentar a produtividade.

Entretanto, em São Paulo, as usinas utilizavam as variedades com melhor aproveitamento do que nas demais regiōes. A precisão na combinação de variedades e técnicas de cultivo era o diferencial. A criação do CTC, em 1970, reforçaria a capacidade das empresas paulistas de gerar seu próprio conhecimento e difundir tecnologias. Mantido o trabalho de assistência técnica, o CTC passou a pesquisar variedades de cana e desenvolver tecnologias industriais próprias. A instituiçãa não se fechou em si, mas buscou agregar competências nacionais, como a Empresa Brasileira de Pesquisa Agropecuária - Embrapa, e internacionais (CESNICK, 2006).

$\mathrm{O}$ resultado final é que o motor de transformação trouxe resultados distintos para o SPIS. O primeiro foi o fortalecimento da produtividade agroindustrial de São Paulo. As empresas participantes do trabalho com o IAC ou com o CTC tiveram acesso a uma ampla rede de difusão de conhecimentos. Foi em São Paulo que a FSI de difusão de conhecimentos se desenvolveu plenamente na evolução do motor de transformação. A mobilização de recursos das empresas paulistas foi indispensável para alcançar estes resultados. O reconhecimento da importância dos trabalhos de experimentação agrícola culminou na criação do CTC, que, além de fortalecer a assistência técnica, passou a gerar tecnologias e conhecimentos próprios.

Nas demais regióes, o aumento da produtividade se deu, quase que exclusivamente, em função do uso das novas variedades. Entretanto, o sistema de cultivo não 
explorava todo o potencial das variedades, gerando ineficiências produtivas. O SPIS evoluiu de forma geograficamente desbalanceada. A Figura 6 apresenta o motor de transformação relacionado ao desenvolvimento de variedades.

FIGURA 6

Representação esquemática do motor de transformação do desenvolvimento de variedades após a crise do mosaico

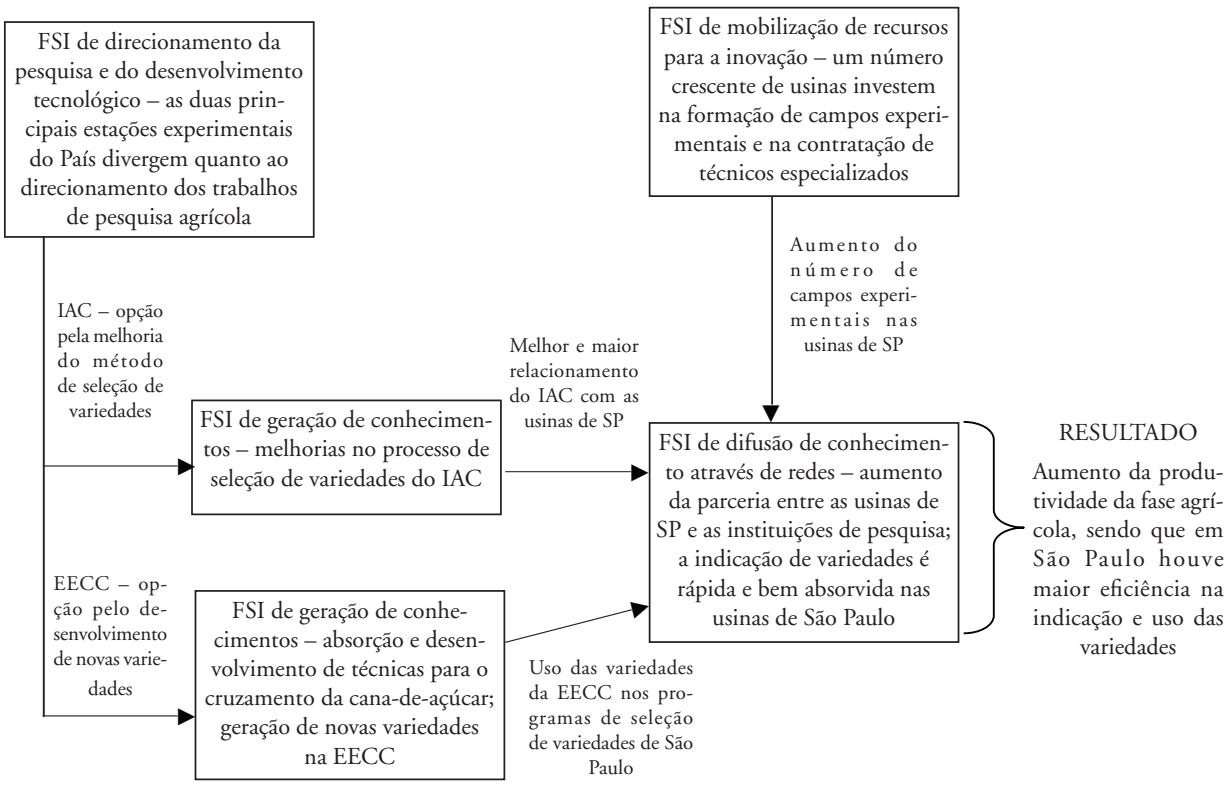

Fonte: Elaboração própria.

\subsection{A expansão produtiva da agroindústria sucroalcooleira em São Paulo}

O motor de transformação da estrutura produtiva agroindustrial voltaria a se desenvolver entre as décadas de 1940 e 1970. A motivação da mudança tem origem na Segunda Guerra, quando o abastecimento do mercado de açúcar do centro-sul sofreu interrupções em função do ataque de submarinos na costa brasileira (SANTOS, 1982). Antes da Guerra, o mercado brasileiro de açúcar era abastecido pelo produto nordestino, cabendo às empresas do centro-sul, especialmente de São Paulo, a distribuição do produto.

Com a interrupção do abastecimento, o governo federal adotou medidas para minimizar o problema da oferta de açúcar. Enquanto durassem os efeitos da Guer- 
ra, a produção de açúcar seria flexibilizada por meio da autorização para instalação de engenhos ${ }^{7}$ de até 400 sacos, bastando comunicação à prefeitura local. Passado o período da Guerra, as quotas foram oficializadas pelo IAA, órgão de controle da produção açucareira. Os empresários paulistas iniciaram a instalação de novas usinas, partindo da fusão de quotas de 400 sacos (QUEDA, 1972). Reunindo uma quota mínima de 3.000 sacos, era possível instalar uma usina em pleno acordo com as normas do Estatuto da Lavoura Canavieira (BRASIL, 1941).

O período da Guerra mostrou aos empresários paulistas que a produção açucareira era uma boa oportunidade de negócios. Os empresários do café investiram capitais na produção açucareira, aproveitando a conjuntura favorável que reunia: disponibilidade de quotas de produção; exploração de uma atividade rentável; e mercado interno crescente e que ainda permitia diversificar os negócios em função da estagnação da atividade cafeeira.

Num período de 40 anos, o empreendedorismo paulista resultou na inversão de posição com Pernambuco, principal Estado produtor da Região Nordeste. Na safra de 1930/31, Pernambuco respondia por 37,7\% da produção de açúcar e São Paulo por 13,4\%. Já na safra de 1951/52, a produção de ambos os Estados foi praticamente idêntica, enquanto na de 1970/71 Pernambuco produziu 18,4\% do total do país e São Paulo 47,5\%.

A análise da estrutura produtiva disponível em Pernambuco e São Paulo traz informaçōes importantes para compreender as alterações no SPIS. No início da década de 1930, Pernambuco dispunha de maior número de usinas, que também eram de maior escala. A situação começou a se reverter na safra de 1947/48, quando houve um salto no número de usinas em São Paulo. Entretanto, a maior parte das usinas de São Paulo (56\%) tinha capacidade produtiva inferior a 50 mil sacos. A baixa capacidade reflete o início do processo de fusão de quotas. Segundo Queda (1972), o período que teve início na década de 1950 foi o mais significativo para as usinas de São Paulo, que aumentaram sua produção com as melhorias introduzidas no processo industrial. No começo dos anos 1970, o parque agroindustrial paulista era amplo, com unidades de alta escala produtiva. A comparação com Pernambuco confirma a estagnação das atividades naquele Estado e a evolução em São Paulo.

Em São Paulo, a FSI empreendedora se desenvolveu em sintonia com a FSI de criação de legitimidade e contenção da resistência à mudança. Conforme visto anteriormente, a divisão das atividades agrícola e industrial fez surgir a categoria

7 Neste caso, são as tradicionais unidades produtoras de açúcar com tecnologias rudimentares. Não confundir os engenhos de até 400 sacos com os engenhos centrais, de maior capacidade e melhor tecnologia. 
de fornecedores de cana-de-açúcar. No Nordeste, os fornecedores de cana tinham origem nos antigos senhores de engenho, gerando diversos conflitos em função de sua força política. Já em São Paulo a situação era diferente, pois a cultura canavieira incorporou áreas novas para a atividade. A região centro-oeste paulista tinha tradição na cultura do café, onde os trabalhadores rurais estavam organizados através do sistema de colonato. Assim, um ano antes da criação do Estatuto da Lavoura Canavieira (em 1941), os usineiros paulistas utilizavam 88,7\% de canas próprias, percentual significativamente maior do que o verificado no Rio de Janeiro $(42,2 \%)$ e Pernambuco (47,2\%).

A grande participação de canas próprias em São Paulo se explica em função de a expansão da atividade canavieira ter ocorrido com a decadência da cafeicultura. $\mathrm{O}$ cultivo do café era feito em grandes propriedades que posteriormente serviram para a lavoura da cana. O sistema de trabalho era o colonato, no qual a usina era proprietária da terra e os trabalhadores eram remunerados pelo trabalho agrícola. O sistema de colonato constituía fenômeno sui generis originado nas novas regiōes produtoras do Estado de São Paulo (RAMOS, 1983).

O Estatuto da Lavoura Canavieira fixou o limite máximo de $60 \%$ para o uso de canas das próprias usinas, o que não interessava aos empresários paulistas (BRASIL, 1941). A publicação do Decreto-lei $9.827 / 46$ possibilitou um relaxamento nos limites que impediam a expansão da agroindústria paulista (BRASIL, 1946). Entretanto, mesmo com a flexibilização da legislação, as usinas paulistas estavam submetidas a limites de uso de canas próprias. Então, como explicar a expansão da atividade açucareira de São Paulo sem que houvesse conflitos entre fornecedores e usineiros e sem ter problemas com a fiscalização do IAA?

Ramos (1983) analisa em profundidade a real estrutura fundiária que se desenvolveu em São Paulo. Desde a década de 1940, os usineiros paulistas buscaram formas alternativas de contornar os limites para a produção de canas próprias. $\mathrm{O}$ autor observa que muitos dos fornecedores de usinas eram seus prepostos. Neste caso, as usinas eram proprietárias ou arrendatárias de terras, cultivando-as em seu interesse, mas em nome de terceiros. Uma segunda forma de burlar a legislação era a transferência real das propriedades sem a efetiva transferência legal no cartório de registro de imóveis. Dessa forma, as usinas adquiriam as terras mediante contratos de compra e venda que não eram registrados no cartório específico. $\mathrm{O}$ arrendamen-

8 É preciso observar que a situação aqui descrita não era válida para a região de Piracicaba. A região de Piracicaba era mais antiga na produção de açúcar e apresentava conflitos semelhantes aos verificados em Campos e no Nordeste, ainda que em menor intensidade. 
O resultado do quinto motor de transformação foi a ampliação da escala de produção das usinas, fenômeno que se apresentou com maior intensidade no Estado de São Paulo. As usinas paulistas seguiram a trajetória natural de ganhos de escala, aumentando a competitividade por meio da redução dos custos de produção. $\mathrm{O}$ SPIS cresceu em sua capacidade de processar cana-de-açúcar.

\subsection{0 relacionamento da agroindústria sucroalcooleira com a indústria de equipamentos}

O motor de transformação que estruturou atividades de produção em São Paulo se desenvolveu em co-evolução com outro motor de transformação, o que proporcionou o estabelecimento de relações duradouras entre a agroindústria do açúcar e do álcool e a indústria de equipamentos. O sexto motor identificado foi motivado pela oportunidade de atender à demanda por equipamentos, gerada pelo crescimento agroindustrial do setor e reforçada pela política de substituição de importações.

Negri (1977) estudou a formação da indústria de equipamentos e identificou que, em São Paulo, o crescimento agroindustrial acelerado foi responsável pelo surgimento de empresas fornecedoras de serviços e produtos para as usinas. O crescimento da agroindústria sucroalcooleira paulista apresentou as características de ser rápido e geograficamente concentrado. $\mathrm{O}$ aumento da produção foi acompanhado por uma demanda de serviços de reparo e fornecimento de novos equipamentos. As empresas europeias que tradicionalmente atendiam ao mercado brasileiro não conseguiam responder com a velocidade requerida pela nova dinâmica produtiva. Constituiu-se, assim, um ambiente propício ao desenvolvimento da FSI de formação de mercado.

A FSI de formação de mercado impulsionou os empresários a extraírem vantagens da nova oportunidade de negócio, prestando serviços com maior agilidade e fornecendo equipamentos ajustados à necessidade de cada cliente. Ao menos 20 empresas produziam e comercializavam equipamentos para as diversas etapas da produção do açúcar e do álcool, das quais 17 estavam localizadas no Estado de São Paulo, sendo 13 em Piracicaba. A criação de empresas para atender ao novo mercado permite mapear a existência da FSI de atividades empreendedoras.

As empresas fornecedoras de equipamentos competiam entre si com a oferta de diferentes tecnologias. O desenvolvimento tecnológico foi importante para aumentar o rendimento dos processos e as escalas de produção. Entre as empresas do 
setor, destacam-se as do Grupo Dedini, formado pela M. Dedini S/A Metalúrgica e pela Codistil - Construtora de Destilarias Dedini S/A. A Dedini exemplifica a capacidade da indústria de equipamentos no desenvolvimento de tecnologias. $\mathrm{O}$ Grupo iniciou as atividades com a utilização de tecnologias de domínio público, passou a elaborar projetos com a equipe de engenheiros e, finalmente, desenvolver tecnologias próprias. Para a produção de álcool, num período de menos de 30 anos, as destilarias fornecidas pela Codistil tiveram um aumento de escala de quase 20 vezes, passando de $12 \mathrm{mil}$ para $220 \mathrm{mil} \mathrm{litros/dia.} \mathrm{Processo} \mathrm{semelhante} \mathrm{ocorreu} \mathrm{com}$ os equipamentos de beneficiamento do açúcar. A FSI de geração de conhecimento é identificada no desenvolvimento do motor de transformação.

Entretanto, o evento mais significativo na transformação do SPIS foi o estreito relacionamento entre os fornecedores e a agroindústria sucroalcooleira, especialmente no Estado de São Paulo. Negri (1977) avalia a política comercial implementada pelo Grupo Dedini como a mais relevante. A Dedini realizava a venda de equipamentos novos aceitando parte do pagamento em equipamentos usados, que eram modernizados e vendidos para usinas de menor porte. A empresa também se tornava sócia de novas usinas, fornecendo equipamentos na forma de integralização de capital. A participação de mercado do Grupo Dedini era bastante significativa para o setor (54,5\% em 1975). Ainda que em menor abrangência, o Grupo Zanini também surgiu da associação da indústria de equipamentos com a agroindústria. Segunda no volume de vendas, a Zanini detinha $14,0 \%$ das vendas de equipamentos em 1975. A estratégia dos fornecedores de equipamentos permitiu o crescimento da Dedini e um verdadeiro processo de modernização da estrutura produtiva. A Figura 8 representa o sexto motor de transformação identificado no SPIS.

Numa primeira avaliação, o evento mapeado por Negri (1977) poderia ser classificado como a FSI de difusão de conhecimentos através de redes. Apesar de cumprir o papel de difusão de tecnologias embarcada nos equipamentos, a principal característica do evento foi o estreito relacionamento entre a agroindústria e a indústria de equipamentos, que incluía formas diferenciadas de compra/venda de equipamentos e formação de sociedades, o que pode ser entendido como uma nova FSI: relacionamento entre a estrutura produtiva e seus fornecedores. 
FIGURA 8

Representação esquemática do motor de transformação que resultou no crescimento da indústria de equipamentos para a produção de açúcar e álcool

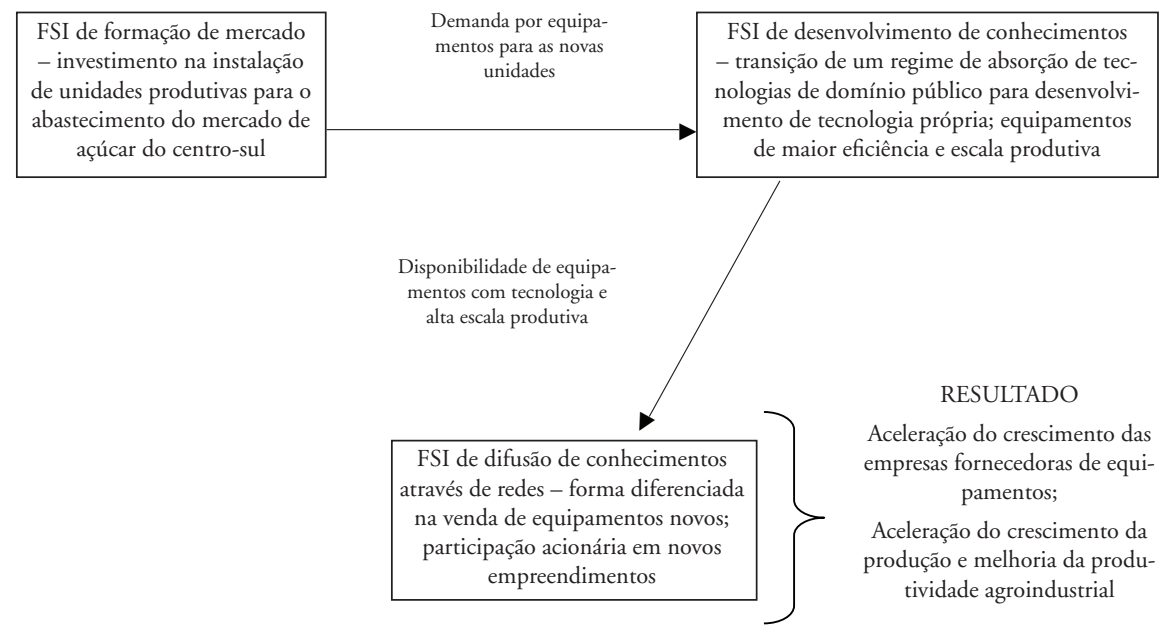

Fonte: Elaboração própria.

\section{Conclusões}

O artigo demonstrou que o período anterior a 1975 foi fundamental para a estruturação do SI em álcool combustível, identificando seis motores de transformação que influenciaram na realização de atividades de inovação e no crescimento da produção: 1) o processo de modernização de 1875 e a instalação dos engenhos centrais; 2) superação da crise do mosaico; 3) formação do mercado de álcool combustível; 4) o desenvolvimento de variedades de cana após a crise do mosaico; 5) a expansão produtiva da agroindústria sucroalcooleira em São Paulo; 6) o relacionamento da agroindústria sucroalcooleira com a indústria de equipamentos.

No ano de lançamento do Proálcool, o Brasil dispunha de um mercado de álcool combustível formado, de uma estrutura de pesquisa agrícola desenvolvida, de fornecedores de equipamentos capacitados tecnologicamente e de um parque industrial minimamente montado. Fator igualmente importante na execução do Proálcool foi a existência prévia de relações entre os agentes produtivos. Na experimentação agrícola, a relação ocorreu através das redes de difusão de tecnologias; e, na modernização tecnológica do setor, por meio do relacionamento entre os for- 
necedores e a agroindústria. O Quadro 1 resume as características dos seis motores de transformação.

Os motores de transformação permitem uma abordagem sistêmica da inovação, detalhando aspectos centrais para o processo de mudança dos níveis tecnológicos e produtivos. As FSI cumprem este papel de detalhamento, melhorando o entendimento das transformações ocorridas. A metodologia, inspirada em Hekkert et al. (2007), foi adaptada para incluir outros componentes que se demonstraram importantes. A ferramenta de análise pode ser aplicada a outras indústrias, desde que exista uma base prévia de dados históricos.

QUADRO 1

Motores de transformação identificados para o SI em álcool combustível

\begin{tabular}{|c|c|c|c|c|c|c|}
\hline Motores & $\begin{array}{l}\text { Processo de } \\
\text { modernização } \\
\text { de } 1875\end{array}$ & $\begin{array}{c}\text { Superação } \\
\text { da crise do } \\
\text { mosaico }\end{array}$ & $\begin{array}{l}\text { Formação do } \\
\text { mercado de } \\
\text { álcool }\end{array}$ & $\begin{array}{c}\text { Desenvolvi- } \\
\text { mento de } \\
\text { variedades de } \\
\text { cana }\end{array}$ & $\begin{array}{c}\text { Expansão } \\
\text { produtiva em } \\
\text { São Paulo }\end{array}$ & $\begin{array}{c}\text { Relacionamento } \\
\text { com a } \\
\text { indústria de } \\
\text { equipamentos }\end{array}$ \\
\hline $\begin{array}{c}\text { Motivação } \\
\text { da mudança }\end{array}$ & $\begin{array}{l}\text { Aumentar a } \\
\text { competitividade } \\
\text { do açúcar } \\
\text { no mercado } \\
\text { internacional }\end{array}$ & $\begin{array}{l}\text { Recuperar, com } \\
\text { urgência, a } \\
\text { produtividade } \\
\text { do açúcar }\end{array}$ & $\begin{array}{l}\text { Desviar o } \\
\text { excedente do } \\
\text { açúcar para a } \\
\text { produção de } \\
\text { álcool }\end{array}$ & $\begin{array}{l}\text { Aumentar a } \\
\text { produtividade da } \\
\text { cana-de-açúcar }\end{array}$ & $\begin{array}{l}\text { Aproveitar } \\
\text { oportunidades } \\
\text { no mercado } \\
\text { paulista de } \\
\text { açúcar }\end{array}$ & $\begin{array}{l}\text { Aproveitar } \\
\text { a crescente } \\
\text { demanda por } \\
\text { equipamentos }\end{array}$ \\
\hline Inovação & $\begin{array}{l}\text { Aquisição } \\
\text { e uso de } \\
\text { equipamentos } \\
\text { industriais } \\
\text { modernos }\end{array}$ & $\begin{array}{l}\text { Organização de } \\
\text { um sistema de } \\
\text { experimentação } \\
\text { e difusão de } \\
\text { tecnologia } \\
\text { agrícola }\end{array}$ & $\begin{array}{l}\text { Aquisição e uso } \\
\text { de destilarias } \\
\text { de álcool } \\
\text { anidro }\end{array}$ & $\begin{array}{l}\text { Melhoramento } \\
\text { genético da } \\
\text { cana e difusão } \\
\text { de tecnologias } \\
\text { agrícolas }\end{array}$ & $\begin{array}{l}\text { O motor girou } \\
\text { em torno do } \\
\text { aumento das } \\
\text { escalas de } \\
\text { produção }\end{array}$ & $\begin{array}{l}\text { Equipamento de } \\
\text { maior porte e com } \\
\text { tecnologia própria }\end{array}$ \\
\hline $\begin{array}{c}\text { FSI } \\
\text { envolvidas }\end{array}$ & $\begin{array}{l}\text { FSI 1, FSI 4, } \\
\text { FSI } 6 \text { e FSI } 7\end{array}$ & $\begin{array}{l}\text { FSI 2, FSI 3, } \\
\text { FSI } 4\end{array}$ & $\begin{array}{l}\text { FSI 1, FSI 5, } \\
\text { FSI } 7\end{array}$ & $\begin{array}{l}\text { FSI 2, FSI 3, FSI } 4 \\
\text { e FSI } 6\end{array}$ & FSI 1 e FSI 7 & $\begin{array}{l}\text { FSI 1, FSI } 2 \\
\text { FSI } 5 \text { e FSI de } \\
\text { relacionamento } \\
\text { com fornecedores }\end{array}$ \\
\hline $\begin{array}{c}\text { Resultados } \\
\text { obtidos }\end{array}$ & $\begin{array}{l}\text { O motor } \\
\text { falhou. A } \\
\text { modernização } \\
\text { não foi } \\
\text { alcançada. } \\
\text { Resultado } \\
\text { colateral: } \\
\text { criação dos } \\
\text { fornecedores } \\
\text { de cana. }\end{array}$ & $\begin{array}{l}\text { O motor } \\
\text { transformou o } \\
\text { SI. A crise do } \\
\text { mosaico foi } \\
\text { superada. }\end{array}$ & $\begin{array}{l}\text { O motor } \\
\text { transformou o } \\
\text { SI. O mercado } \\
\text { de álcool foi } \\
\text { formado. }\end{array}$ & $\begin{array}{l}\text { O motor } \\
\text { transformou } \\
\text { o SI de forma } \\
\text { desigual, sendo } \\
\text { mais intensa em } \\
\text { São Paulo do } \\
\text { que no resto do } \\
\text { Brasil. }\end{array}$ & $\begin{array}{l}\text { O motor } \\
\text { transformou o } \\
\text { SI em São Paulo, } \\
\text { aumentando } \\
\text { o parque } \\
\text { agroindustrial. }\end{array}$ & $\begin{array}{l}\text { O motor } \\
\text { transformou o } \\
\text { SI em São Paulo, } \\
\text { acelerando a } \\
\text { modernização } \\
\text { agroindustrial. }\end{array}$ \\
\hline
\end{tabular}

Fonte: Elaboração própria.

Da análise dos motores de transformação, verifica-se que o sexto motor apresenta uma FSI não prevista por Hekkert et al. (2007). O motor indica que os fornecedores de equipamentos foram importantes para dinamizar o SPIS, estabelecendo relações com a agroindústria sucroalcooleira. Os fornecedores de equipamentos 
supriram as usinas com inovaçôes que transformaram o SPIS. Trata-se de uma FSI que a abordagem teórica não previa. Considerando as características gerais de outras indústrias, é possível inferir que esta nova FSI seja relevante para o estudo de SI em geral. Relações semelhantes parecem ter ocorrido em outros SI do agronegócio brasileiro, como é o caso da integração produtiva desenvolvida entre os frigoríficos e os criadores de aves e suínos.

No artigo foram analisados motores que influenciaram positivamente na transformação do SPIS e motores que não se desenvolveram com êxito. $\mathrm{O}$ estudo das falhas no desenvolvimento dos motores de transformação é ferramenta de análise útil para os gestores de políticas públicas. Com base na razão das falhas, a ação do Estado pode ser redirecionada para evitar distorçōes na estruturação dos SI. Isso é particularmente verdadeiro ao se analisar o fracasso do direcionamento tecnológico, quando o governo privilegiou o uso do método de difusão em substituição às moendas de cana.

Uma breve análise das falhas associadas ao processo de modernização da agroindústria sucroalcooleira no final do século XIX indica que a dimensão tecnológica não foi suficiente para a transformação do SI. A implementação dos engenhos centrais alterou os modelos de relacionamento produtivo-comercial existentes até aquela época. A separação da atividade agroindustrial em duas fases distintas e com agentes econômicos distintos - produtores de cana-de-açúcar e industriais do açúcar - buscou responder à necessidade de suprir a demanda de matérias-primas dos engenhos centrais. Entretanto, o relacionamento entre os agentes econômicos foi pouco eficaz, com conflitos entre produtores e industriais. $\mathrm{O}$ valor gerado pela mudança tecnológica não foi adequadamente distribuído dentro da nova configuração produtiva. A dimensão institucional parece não ter favorecido a difusão e o uso da tecnologia fomentada pelo governo.

O artigo também permite observar o caráter exógeno das inovações. As usinas de açúcar e álcool foram dependentes de inovaçóes desenvolvidas por outros agentes do SI. As instituições públicas de pesquisa foram essenciais para a melhoria da produtividade de cana, além de melhorias nos aspectos sanitários da cultura - resistência a pragas e doenças. A indústria de bens de capital desenvolveu e ajudou na difusão de equipamentos de melhor desempenho, aumentando as escalas de produção e os índices técnicos de rendimento. Essas características justificam a classificação da indústria sucroalcooleira como supplier dominated, na tipologia proposta por Pavitt (1984). 
$\mathrm{O}$ crescimento da atividade alcooleira só foi possível em função de esforços tecnológicos exógenos aos produtores de álcool. O aumento do padrão tecnológico da indústria foi impulsionado pelos fornecedores de tecnologia - instituições de pesquisa agrícola e fornecedores de bens de capital - e o crescimento puxado por novos usos para a cana-de-açúcar - o álcool combustível.

Apesar de estar fora do escopo do presente artigo, é preciso observar ainda que, no período do Proálcool, a agroindústria sucroalcooleira foi dependente de inovações exógenas relacionadas ao uso de seus produtos, notadamente o álcool combustível. O desenvolvimento do carro a álcool foi realizado pelas empresas automotivas, ainda que motivadas por um contexto complexo que reunia interesses governamentais e da própria indústria sucroalcooleira. O estudo detalhado dessas dimensões pode trazer aspectos importantes para a formulação de políticas públicas e o posicionamento de empresas relacionadas ao mercado sucroalcooleiro e de biocombustíveis.

\section{Referências bibliográficas}

BRASIL. Decreto n. 2.687, de 06 de novembro de 1875. Autoriza o Governo para conceder, sob certas cláusulas, ao Banco de Credito Real que se fundar segundo o plano da Lei ${ }^{\circ}$ 1.237 de 24 de Setembro de 1864, garantia de juros e amortização de suas letras hipotecárias, e bem assim para garantir juros de $7 \%$ às companhias que se propuserem a estabelecer engenhos centrais para fabricar açúcar de cana. Rio de Janeiro, Secretaria de Estado dos Negócios da Fazenda, Governo Imperial, 1875.

BRASIL. Decreto n. 8.357, de 24 de dezembro de 1881. Aprova o regulamento para as concessões de engenhos centrais, com garantia de juros ou fiança do Estado. Rio de Janeiro, Governo Imperial, 1881.

BRASIL. Decreto n. 10.393, de 09 de outubro de 1889. Dá regulamento para execução do decreto legislativo n. 2.687 de 6 de novembro de 1875 na parte referente à fundação de engenhos centrais para fabrico de açúcar e de álcool de cana. Rio de Janeiro, Governo Imperial, 1989.

BRASIL. Decreto n. 819, de 04 de outubro de 1890. Declara temporariamente facultativa a adoção do sistema da difusão e institui prêmios para animar o aperfeiçoamento progressivo do fabrico do açúcar no Brasil. Diário Oficial da Uniāo, Poder Executivo, Rio de Janeiro, 1890.

BRASIL. Decreto n ${ }^{\circ}$ 19.717, de 20 fevereiro de 1931. Estabelece a aquisição obrigatória de álcool, na proporção de $5 \%$ (cinco por cento) da gasolina importada, e dá outras providências. Diário Oficial da União, Poder Executivo, Rio de Janeiro, 1931a. 
BRASIL. Portaria de 04 de agosto de 1931. Estabelece providências para a execução do decreto 19.717, de 20 de fevereiro de 1931. Ministério da Agricultura, Poder Executivo, Rio de Janeiro, 1931b.

BRASIL. Decreto-Lei n. 3.855, de 21 de novembro de 1941. Estatuto da Lavoura Canavieira. Diário Oficial da União, Poder Executivo, Rio de Janeiro, 1941.

BRASIL. Decreto-Lei n. 9.827, de 10 de setembro de 1946. Dispõe sobre a produção açucareira e dá outras providências. Diário Oficial da Uniāo, Poder Executivo, Rio de Janeiro, 1946.

BRASIL. Ministério da Agricultura, Comércio e Obras Públicas - Macop. Relatório de atividades. Rio de Janeiro, Imprensa Nacional, junho 1891.

BRASIL. Ministério da Agricultura - MA. Relatórios de atividade. Rio de Janeiro, Imprensa Nacional, diversos números 1920 a 1938.

BRESCHI, S.; MALERBA, F. Sectoral systems of innovation: technological regimes, Schumpeterian dynamics and spatial boundaries. In: EDQUIST, C. (Ed.). Systems of innovation. London: Frances Pinter, 1997.

CESNIK, R. Melhoramento da cana-de-açúcar: marco sucroalcooleiro no Brasil. 2006. Disponível em: <www.comciencia.br>. Acesso em: 06 ago. 2007.

DEPARTAMENTO NACIONAL DE PROPANGANDA - DNP. O açúcar sob o governo Getúlio Vargas. Editora Amorim e Cia, 1938.

EISENBERG, P. L. Modernização sem mudança: a indústria açucareira em Pernambuco 1840-1910. Rio de Janeiro: Editora Paz e Terra, 1977 (Coleção Estudos Brasileiros, v. 15).

ESTAÇÃO EXPERIMENTAL DE CANA DE CAMPOS - EECC. Ata da reuniāo técnica do cinqüentenário da Estação Experimental de Campos - RJ. Publicação da Estação Experimental de Campos. Campos-RJ, 8 de novembro 1963.

GEELS, F. W. From sectoral systems of innovation to socio-technical systems: insights about dynamics and change from sociology and institutional theory. Research Policy, v. 33, p. 897-920, 2004.

HEKKERT, M. P. et al. Functions of innovation systems: a new approach for analysing technological change. Technological Forecasting and Social Change, v. 74, p. 413-432, 2007.

JÚNIOR, J. A. Criação de novas variedades no Estado de São Paulo. Piracicaba, Instituto Agronômico de Campinas, 1936 (Boletim técnico, n. 34).

NEGRI, B. Um estudo de caso da indústria nacional de equipamentos: análise do grupo Dedini (1920-1975). Dissertação (Mestrado). Campinas: IFCH, Universidade Estadual de Campinas, 1977. 
OLIVER, G. S. José Vizioli e o início da modernização tecnológica da agroindústria canavieira paulista (1919-1949). Dissertação (Mestrado). Campinas: Instituto de Geociências, Universidade Estadual de Campinas, 2001.

OLIVER, G. S.; SZMRECSÁNYI, T. A Estação Experimental de Piracicaba e a modernização tecnológica da agroindústria canavieira (1920-1940). Revista Brasileira de História, v. 23, n. 46, p. 37-60, 2003.

MALERBA, F. Sectoral systems of innovation: basic concepts. In: MALERBA, F. (Ed.). Sectoral Systems of Innovation. Cambridge: Cambridge University Press, 2004, p. 9-41.

MALERBA, F.; ORSENIGO, L. Technological regimes and sectoral patterns of innovative activities. Industrial and Corporate Change, v. 6, p. 83-117, 1997.

MELO, J. A política do álcool-motor no Brasil. Rio de Janeiro: IAA, 1942.

NELSON, R. R.; WINTER, S. G. An evolutionary theory af economic change. Harvard U.s, 1982.

PAVITT, K. Sectoral patterns of technical change: towards a taxonomy and a theory. Research Policy, v. 13, p. 343-373. 1984.

QUEDA, A. A intervenção do Estado e a agroindústria açucareira paulista. Dissertação (Doutorado). Piracicaba, Escola Superior de Agricultura Aloísio de Queiroz, Universidade de São Paulo, 1972.

RAMOS, P. Um estudo da evolução e da estrutura da agroindústria canavieira do Estado de São Paulo (1930-1982). Dissertação (Mestrado). São Paulo, EAESP, Fundação Getúlio Vargas, 1983.

REVISTA BRASIL AÇÚCAREIRO. Publicação do Instituo do Açúcar e do Álcool. Diversos números, 1950 a 1975.

SANTOS, M. H. Álcool: subproduto do açúcar ou combustível? Uma perspectiva histórica (1900-1975). Rio de Janeiro: Finep, 1982.

SOCIEDADE NACIONAL DE AGRICULTURA - SNA. Exposição Internacional de Aparelhos a Álcool. A Lavoura, Rio de Janeiro, v. out.-nov. de 1903, 1904. 
Fabrício Brollo Dunham, José Vitor Bomtempo, Denise Lima Fleck

ENDEREÇOS PARA CORRESPONDENCIA:

Fabrício Brollo Dunham - fbdunham@ig.com.br

Engenheiro do Banco Nacional de Desenvolvimento Econômico e Social (BNDES)

Av. Chile, 100

20031-917 - Rio de Janeiro (RJ)

Tel. (21) 2172-7447

José Vitor Bomtempo - vitor@eq.ufrj.br

Gestão e Inovação Tecnológica, Escola de Química (UFRJ)

Grupo de Economia da Energia, Instituto de Economia (UFRJ)

Av. Pasteur, 250

22290-240 - Rio de Janeiro (RJ)

Tel./Fax: (21) 2562-7610

Denise Lima Fleck - denise@coppead.ufrj.br Instituto COPPEAD

Rua Pacoal Leme, 355 - Ilha do Fundão

21941-918 - Rio de Janeiro (RJ) 